\title{
Pemeriksaan Laju Endap Darah (LED) Pada Ibu Hamil Di Rumah Sakit Annisa Pekanbaru
}

\author{
Hotmauli ${ }^{1 *}$, Imelda Fitri ',Harni Sepriani' dan Brilian Dini MA. Iballa ${ }^{4}$ \\ 1 Fakultas Farmasi dan Ilmu Kesehatan, Universitas Abdurrab, Jl. Riau Ujung No.73 Pekanbaru, Riau \\ 28291, Indonesia \\ Email korespondensi: Hotmauli@univrab.ac.id
}

\begin{abstract}
Pregnancy is a condition in which a woman has a fetus in her body that is developing in the womb. The condition of the prospective mother in the early stages of pregnancy will affect the success rate of pregnancy, so it is recommended for prospective mothers to maintain a healthy lifestyle. Pregnant women are very susceptible to anemia, this is due to the increased need for iron in the mother's body, along with increasing gestational age. Anemia in pregnancy is a major health problem in developing countries with high morbidity rates in pregnant women. The erythrocyte sedimentation rate (ESR) is one of the complete blood tests carried out in the examination of pregnant women. ESR is also one of the hematological tests or blood tests to measure how long it takes for red blood cells to settle. An increase in the ESR value indicates the presence of infection, inflammatory or autoimmune disease, rheumatic feverexamination of the erythrocyte sedimentation rate in pregnant women at Annisa Hospital Pekanbaru. This type of research is descriptive research. The results showed that from 33 respondents, pregnant women at Annisa Hospital Pekanbaru had an LED value of $10-50 \mathrm{~mm} /$ hour. The conclusion of this study is that pregnant women with normal ESR values were 7 respondents with an average of $9.43 \mathrm{~mm} /$ hour and ESR in abnormal pregnant women were 26 respondents with an average of $38.19 \mathrm{~mm} /$ hour.
\end{abstract}

Keywords : : Blood, LED and pregnant mother.

\section{PENDAHULUAN}

Kehamilan adalah keadaan dimana perempuan memiliki janin didalam tubuhnya yang sedang berkembang didalam rahim. Kehamilan pada manusia berkisaran 9 bulan atau 40 minggu, dihitung dari terakhir kali hari menstruasi sampai melahirkan. Kehamilan merupakan suatu proses reproduksi yang harus mendapatkan perlakuan khusus dalam menanganinya, supaya dapat berlangsung dengan baik dan juga tidak membahayakan kehidupan sang ibu maupun bayi yang ada didalam kandungan. Resiko kehamilan bersifat dinamis, dimana sang ibu yang mulanya normal, secara tiba-tiba dapat berisiko tinggi yang dapat membahayakan nyawa sang ibu dan juga bayinya (Maternity, 2017). 
Kondisi calon ibu pada masa awal kehamilan akan mempengaruhi tingkat keberhasilan kehamilan, sehingga disarankan agar calon ibu menjaga prilaku hidup sehat. Ibu juga diharapkan menghindari faktor-faktor yang mempengaruhi prilaku hidup tidak sehat agar kondisi calon bayi menjadi sehat pada masa kehamilan (Johnson, 2016).

Ibu hamil sangat rentan mengalami anemia. Hal itu disebabkan oleh meningkatnya kebutuhan tubuh ibu akan zat besi, seiring dengan bertambahnya usia kehamilan.Anemia dalam kehamilan merupakan masalah kesehatan yang utama di negara berkembang dengan tingkat morbiditas tinggi pada ibu hamil.Saat ibu mengalami anemia, ibu tidak memiliki sel darah merah yang cukup sehat untuk mengangkut oksigen ke jaringan dan kepada janin. Jika ibu tidak bisa mendapatkan zat besi yang cukup atau nutrisi penting lainnya, maka tubuh ibu tidak akan mampu memproduksi sel darah merah (Adawiyani, 2013).

LED merupakan salah satu pemeriksaan darah lengkap yang dilakukan dalam pemeriksaan ibu hamil. Faktor-faktor yang mempengaruhi hasil uji LED adalah kadar fibrinogen, rasio sel darah merah dibandingkan dengan plasma, sel darah merah yang abnormal, dan beberapa faktor teknis. Kadar fibrinogen dalam darah akan terjadi peningkatan saat terjadi radang atau infeksi atau menyebabkan sel-sel darah merah lebih mudah menggumpal sehingga sel darah merah lebih cepat mengendap. LED cenderung dikaitkan dengan keberadan radang atau infeksi, namun dapat juga membantu pemantauan kelainan kekebalan tubuh, diabetes, anemia, dan juga merupakan salah satu dari pemeriksaan darah lengkap (Nugraha, 2015).

Saat ibu mengalami anemia, ibu tidak memiliki sel darah merah yang cukup sehat untuk mengangkut oksigen ke jaringan dan kepada janin. Jika ibu tidak bisa mendapatkan zat besi yang cukup atau nutrisi penting lainnya, maka tubuh ibu tidak akan mampu memproduksi sel darah merah (Adawiyani, 2013). Berdasarkan uraian dari latar belakang tujuan khusus dari penelitian ini adalah Mengetahui nilai Laju Endap Darah dengan metode westergreen pada ibu hamil di RSIA Annisa Pekanbaru.

\section{METODE}

Penelitian ini menggunakan desain penelitian deskriptif. Pengambilan dan pemeriksaan sampel dilakukan di Rumah Sakit Annisa Pekanbaru, pada bulan Januari - Maret 2021 atau setelah peneliti mendapat izin persetujuan dari pihak etika penelitian Universitas Abdurrab Pekanbaru Sampel pada penelitian ini sebanyak 33 orang, dengan teknik pengambilan sampel accidental. Alat yang digunakan dalam penelitan ini adalah spuit, alkohol swab 70\%, touniquit, tabung EDTA, handskun, masker, plaster, pipet westergreen, rak westergreen. Bahan-bahan yang digunakan dalam penelitian ini adalah darah vena pada ibu hamil sebagai sampel pemeriksaan, antikoagulan EDTA, larutan natriumsitrat 3,8\%.

Prosedur pengambilan sampel yaitu dengan cara daerah kulit yang akan disuntik dibersihkan dengan kapas alkohol 70\% dan diamkan hingga kering. Pasang tourniquit kira-kita 3 $\mathrm{cm}$ di atas lipatan siku. Tusuk daerah vena dengan posisi lubang jarum menghadap ke atas. Jika jarum telah masuk ke dalam vena, maka darah terlihat masuk kedalam spuit. Usahakan sekali penusukan, lalu tourniquet dilepas. Hisap darah sampai jumlah darah yang diinginkan. Tariklah 
spuit secara perlahandan masukkan darah kedalam tabung yang sudah disediakan (Gandasoebrata, 2011). Prosedur pemeriksaan laju endap darah (Metode Westergreen) yaitu larutan natriumsitrat 3,8\% dihisap sebanyak 0,4 $\mathrm{mL}$. Darah vena sebanyak 1,6 mL sehingga mendapatkan hasil 2,0 mL campuran. Campuran dihomogenkan dan masukkan kedalam pipet Westergreen sampai $0 \mathrm{~mm}$. Pipet diletakkan tegak lurus diatas rak Westergreen selama 60 menit. Tinggi lapisan plasma dibaca dengan millimeter (Gandasoebrata, 2011). Analisis data yang dilakukan dalam pemeriksaan ini yaitu dalam bentuk tabel dan dibahas secara deskriptif.

Tabel 1 Nilai Normal Laju Endap Darah Menggunakan Metode Westergreen

\begin{tabular}{cc}
\hline Nilai Normal LED & Metode Westergreen \\
\hline Pria Dewasa $<50$ tahun & $0-15 \mathrm{~mm} / \mathrm{jam}$ \\
Pria Dewasa $>50$ tahun & $0-20 \mathrm{~mm} / \mathrm{jam}$ \\
Wanita Dewasa $<50$ tahun & $0-20 \mathrm{~mm} / \mathrm{jam}$ \\
Wanita Dewasa $>50$ tahun & $0-30 \mathrm{~mm} / \mathrm{jam}$ \\
\hline
\end{tabular}

\section{HASIL}

Berdasarkan penelitian yang telah dilakukan dilaboratorium rumah sakit Annisa Pekanbaru, terhadap pemeriksaan Laju Endap Darah pada ibu hamil trimester III menggunakan metode westergreen yang dilakukan pada Januari - Maret 2021, kepada 33 responden. Hasil pemeriksaan Laju Endap Darah pada ibu hamil di Rumah Sakit Annisa Pekanbaru dapat dilihat pada tabel 2.

Tabel 2 Pemeriksaan Laju Endaap Darah Pada Ibu Hamil di Rumah Sakit Annisa Kota Pekanbaru.

\begin{tabular}{|c|c|c|c|}
\hline No & $\begin{array}{l}\text { Nama } \\
\text { (inisial) }\end{array}$ & $\begin{array}{c}\text { LED } \\
(\mathrm{mm} / \mathrm{jam})\end{array}$ & Kesimpulan \\
\hline 1 & Ny. FIT & 34 & Tidak Normal \\
\hline 2 & Ny. PUT & 42 & Tidak Normal \\
\hline 3 & Ny. CYI & 31 & Tidak Normal \\
\hline 4 & Ny. FES & 50 & Tidak Normal \\
\hline 5 & Ny. INT & 44 & Tidak Normal \\
\hline 6 & Ny. SIL & 30 & Tidak Normal \\
\hline 7 & Ny. DEW & 39 & Tidak Normal \\
\hline 8 & Ny. ANN & 28 & Tidak Normal \\
\hline 9 & Ny. MEL & 12 & Normal \\
\hline 10 & Ny.NIA & 48 & Tidak Normal \\
\hline 11 & Ny. NZH & 40 & Tidak Normal \\
\hline 12 & Ny. FRI & 10 & Normal \\
\hline 13 & Ny. MAR & 36 & Tidak Normal \\
\hline 14 & Ny. RAJ & 6 & Normal \\
\hline 15 & Ny. AQI & 32 & Tidak Normal \\
\hline 16 & Ny. SIT & 38 & Tidak Normal \\
\hline 17 & Ny. NUR & 30 & Tidak Normal \\
\hline 18 & Ny. FSY & 15 & Normal \\
\hline 19 & Ny. PDW & 42 & Tidak Normal \\
\hline 20 & Ny. RIH & 55 & Tidak Normal \\
\hline 21 & Ny. DID & 10 & Normal \\
\hline 22 & Ny. SFH & 48 & Tidak Normal \\
\hline 23 & Ny. NOR & 3 & Normal \\
\hline 24 & Ny. SUC & 35 & Tidak Normal \\
\hline 25 & Ny. NOV & 30 & Tidak Normal \\
\hline
\end{tabular}




\begin{tabular}{lccc}
26 & Ny. NRA & 51 & Tidak Normal \\
27 & Ny. MIR & 46 & Tidak Normal \\
28 & Ny. MEL & 42 & Tidak Normal \\
29 & Ny. GIN & 25 & Tidak Normal \\
30 & Ny. WAH & 43 & Tidak Normal \\
31 & Ny. SRI & 23 & Tidak Normal \\
32 & Ny. TIK & 31 & Tidak Normal \\
33 & Ny. ASW & 10 & Normal \\
\hline
\end{tabular}

Tabel 2 menunjukkan bahwa nilai LED ibu hamil di RS Annisa yaitu 10-50 mm/jam. Responden yang memiliki nilai Laju Endap Darah tidak normal, yaitu sebanyak 26 responden. Sebagian kecil dari responden memiliki nilai laju endap darah normal, yaitu sebanyak 7 responden. Distribusi Frekuensi Laju Endap Darah pada ibu hamil di Rumah Sakit Annisa Pekanbaru tabel 3.

Tabel 3 Distribusi Frekuensi Laju EndapDarah Pada Ibu Hamil di Rumah Sakit Annisa Pekanbaru Berdasarkan Rerata.

\begin{tabular}{ccccc}
\hline No & Interprestasi & Frekuensi & $\begin{array}{c}\text { Persentase } \\
(\%)\end{array}$ & $\begin{array}{c}\text { Rerata LED } \\
(\mathbf{m m} / \mathbf{j a m})\end{array}$ \\
\hline 1 & Normal & 7 & $21 \%$ & 9,43 \\
2 & Tidak Normal & 26 & $79 \%$ & 38,19 \\
\hline & Jumlah & 33 & $100 \%$ & - \\
\hline
\end{tabular}

Tabel 3 menunjukkan bahwa ibu hamil dengan rerata nilai LED normal adalah 9,43 mm/jam. Ibu hamil dengan rerata LED tidak normal adalah 38,19 mm/jam. Nilai normal LED adalah $0-20$ $\mathrm{mm} / \mathrm{jam}$.

\section{PEMBAHASAN}

Hasil analisis menunjukkan bahwa 26 responden atau sebesar $79 \%$ mengalami peningkatan Laju Endap Darah dan 7 responden atau sebesar 21\% tidak mengalami peningkatran Laju Endap Darah. Peningkatan Laju Endap Darah merupakan kondisi adanya infeksi tertentu pada tubuh yang disebabkan oleh bakteri, virus dan protozoa ( Kiswari, 2014).

Anemia adalah kondisi kadar haemoglobin tidak mencukupi dalam memenuhi kebutuhan fisologi tubuh. Kebutuhan fisologi tersebut berbeda-beda pada setiap orang, berdasarkan usia, jenis kelamin, ketinggian tempat tinggal dari atas laut, dan juga berdasarkan kehamilan (Wirahartati, 2019).

Ibu hamil sangat rentan mengalami anemia disebabkan oleh meningkatnya kebutuhan tubuh ibu akan zat besi, seiring dengan bertambahnya usia kehamilan. Anemia dalam kehamilan merupakan masalah kesehatan yang utama di negara berkembang dengan tingkat morbiditas tinggi pada ibu hamil. Saat ibu mengalami anemia, ibu tidak memiliki sel darah merah yang cukup 
sehat untuk mengangkut oksigen ke jaringan dan kepada janin. Jika ibu tidak bisa mendapatkan zat besi yang cukup atau nutrisi penting lainnya, maka tubuh ibu tidak akan mampu memproduksi sel darah merah (Adawiyani, 2013). LED merupakan salah satu pemeriksaan darah lengkap yang dilakukan dalam pemeriksaan ibu hamil. Laju Endap Darah yang tidak normal tidak dapat menentukan adanya penyakit (Riswanto, 2010).

Berdasarkan hasil penelitian Gilang, tahun 2019 yaitu peningkatan hasil LED pada ibu hamil terdapat dua faktor yang mempengaruhi Laju Endap Darah meningkat yaitu faktor eritrosit dan juga faktor plasma. Selama kehamilan peningkatan volume darah sekitar 1,5 liter, peningkatan volume darah tersebut digunakan untuk memasok kebutuhan dalam janin dan kompensasi kehilanggan darah saat melahirkan. Volume darah meningkat didominasi plasma, peningkatan volume plasma sekitar $10 \%$ sampai $15 \%$ persen. Selain peningkatan plasma, eritrosit juga mengalami peningkatan, tetapi relatif lebih sedikit dibandingkan dengan volume plasma, karena jumlah volume plasma lebih banyak dibandingkan volume eritrosit. Akibatnya terjadi hemodilusi yang ditandai dengan penurunan hematokrit. Penurunan hematokrit sebagai indikator penurunan viskositas darah.

\section{KESIMPULAN}

Berdasarkan penelitian yang dilakukan maka, Ibu hamil dengan rerata nilai LED normal yaitu 9,43 mm/jam sebanyak 7 responden dan Ibu hamil dengan rerata nilai LED tidak normal yaitu 38,19 $\mathrm{mm} / \mathrm{jam}$ sebanyak 26 responden

\section{DAFTAR PUSTAKA}

Adawiyani, R. 2013. Pengaruh Pemberian Booklet Anemia Terhadap Pengetahuan, Kepatuhan Minum Tablet Tambah Darah dan Kadar Hemoglobin Ibu Hamil. Calyptra. Volume 2(2). Halaman 1-20.

Desmawati. 2013. Sistem Hematologi dan Imunologi. Penerbit In Media. Jakarta.

Gandasoebrata, R. 2011. Penuntun Laboratorium Klinik. Cetakan 16. Dian rakyat. Jakarta.

Gilang N, Nur M. 2019. Medicalo Technology and Public Health Journal. Volume 1(1). Halaman 127132.

Johnson, J. 2016. Keperawatan Maternitas Buku Wajib Bagi Praktisi dan Mahasiswa Keperawatan. Rahpa Publishing. Yogyakarta.

Kamuh, M dan Memah. 2015. Gambaran Nilai Hematokrit dan Laju Endap Darah Pada Anak Infeksi Virus Dengue di Manado. Jurnal Kesehatan. Volume 3. Halaman 3. 
Kusmawati, I. 2014.Asuhan Kehamilan. PT. Pustaka Pelajar. Yogyakarta.

Kee, J. 2007. Pedoman Pemeriksaan Laboratorium dan Diagnostik. Ed 6. EGC. Jakarta.

Maternity, D., Putri, R, dan Aulia, D. 2017. Asuhan Kebidanan Komunitas Disesuaikan dengan Pembelajaran Kebidanan. Andi. Yogyakarta

Notoatmodjo, S. 2010. Metodologi Penelitian Kesehatan. Cetakan Ketiga. PT. Rineka Cipta. Jakarta.

Nugraha, G. 2015. Panduan Pemeriksaan Laboratorium Hematologi Dasar. CV Trans Info Media. Jakarta.

Nugraha, G. 2017. Panduan Pemeriksaan Hematologi Dasar Edisi2. CV Trans Info Media. Jakarta.

Pantikawati, S. 2010. Asuhan Kebidanan I (Kehamilan). Nuha Medika. Yogyakarta.

Riswanto, 2011. Hematologi : Jakarta

Sacher, R. 2009. Tinjauan Klinis Terpadu Pemeriksaan Laboratium. EGC. Jakarta.

Syaiful, Ydan Fatmawati, L. 2019. Asuhan Keperawatan Kehamilan. CV Jakad Publishing. Surabaya. Syarif. 2016. Gambaran Pemeriksaan Laju Endap Darah Pada Penderita Anemia di Rumah Sakit Umum Wisata Universitas Indonesia Timur Makassar. Jurnal Kesehatan. Volume 2. Halaman 3.

Sukarni, I dan Wahyu,H. 2013. Kehamilan, Persalinan dan Nifas. Nuha Medika. Yogyakarta.

Wirahartati, L. Herawati, S. Dan Wande, I. 2019. Gambaran Indeks Eritrosit Anemia Pada Ibu Hamil di RSUP Sanglah Denpasar. Jurnal Medika. Volume 8. Halaman 5.

Yusmaidi. 2016. Hubungan Peningkatan Laju Endap Darah dengan Jumlah Leukosit Pada Pasien Apendisitis. Jurnal Medika Malahayati. Volume 3. Halaman 2. 